\title{
Some aspects of telling political jokes in Soviet Estonia ${ }^{1}$
}

\author{
Martin Rebane
}

\begin{abstract}
Despite the fact that information flow in Soviet society was controlled by the political authorities, there were many political jokes in Soviet Estonia. Most jokes during that era tended to be politically motivated as they mocked social conditions, leaders and other grotesque phenomena in the society. Even ethnic jokes had political subtext.

In this article, I will look into the details and reasons for telling such jokes. Qualitative open interviews were conducted for the pilot study to gather information about joke-telling situations and justifications. The limited number of interviews ( 5 altogether) is enough to get hold of the concepts and emotions behind Soviet joke-telling in Estonia, and this will form the basis for my further research on the same issue.
\end{abstract}

Keywords: joke-telling, Soviet jokes, Soviet life, political jokes, political humour, Estonia, totalitarian humour

\section{Introduction}

Soviet society gave rise to many political jokes and scholars have sought to explain their "success" under totalitarian regimes (some examples are Pi-Sunyer 1977 on Spain; Cochran 1989 on Romania; Thurston 1991 on Soviet Union; Bryant 2006 on Czechoslovakia; Krikmann 2009 on Estonia; Hong 2010 on Denmark). Some explanations for massive joking have treated the emergence of jokes as a form of resistance (Obrdlik 1942: 712; Pi-Sunyer 1977: 182) and others as instruments that offer a kind of solace (Hong 2010: 61; Cochran 1989: 272).

For the purpose of this article, I conducted a pilot study to see if I could complement those findings. My goal was to select fruitful but understudied topics touching on Soviet humour in Estonia. Estonia was annexed by the Soviet Union in 1940 and was hence part of the union, and its jokelore, along with all

1 The pilot study is funded by Estonian Science Foundation grant No. ETF8149. 
other walks of life, was greatly influenced by the Soviet occupation. For convenience, I will be using the term "Soviet society" throughout the article, but the empirical part of this study concerns only Estonian society during Soviet occupation. This article clearly attempts to give an overview in the form of a pilot study and does not attempt to make any deeper conclusions.

Political jokes were hardly a weapon that could seriously harm the system (Davies 2011: 246; Hong 2010: 60). They were critical towards communist regime, but cannot be regarded as an instrument to destroy the system. Rather, they represented tiny realms of personal freedom (Davies 2010: 10). Jokes usually do not inform the audience about political issues, but rather comment on them (Tsakona \& Popa 2011: 8-9).

My definition of political joke derives from Speier (1998: 1353-1354): political joke is a joke that has a political allusion of some sort. As has been noted, many different kinds of jokes attained a political dimension in the totalitarian period in Soviet Estonia (Laineste 2008: 29).

\section{Overview of the study}

This research was conducted as a pilot study for my research project designed to analyse the transmission of political jokes in Soviet Estonia. Altogether I conducted 5 interviews lasting 30 to 45 minutes and asked the respondents to tell me about jokes in the 1970s. I selected this specific period because it was the most fruitful in the amount of political jokes (Krikmann 2009). I will use three of the most insightful interviews in this article to give an overview of the findings.

All interviews were unstructured and perhaps only slightly guided. I held qualitative interviews with people aged between 25 to 40 in the 1970s. All respondents held a university degree. I asked general questions about jokes in 1970s. To help my respondents to recall past events (up to 40 years ago), I used "life grid" technique suggested by Blane (1996). This technique helps people to recall past events by cross-referencing different areas of life, e.g. personal life and career.

\section{Interviews}

All respondents took a different view on the question and started from different perspectives. Yet there were similar patterns in their talk. The first pattern was to conclude at some point in the conversation that joking really 
was a widespread phenomenon, far exceeding the amount of joking that one can witness nowadays.

The second pattern was that each one mentioned a few "hubs" where most jokes were told. As respondents came from different backgrounds, the hubs were different. For R1, it was a seminar room where she held refresher courses. R2, who travelled a lot, heard lots of jokes in long distance trains, but also in departmental meetings. R3 was 10 years younger than first 2 respondents and heard most of the jokes in leisure time and while taking part in ideological events where he had to fill obligations enforced by the communist party.

The third pattern was that jokes were often used to cope with the stress arising from the irrational arrangements in Soviet society. I will now describe three situations, each one told by a different respondent. The three respondents described situations where joking might have been the only sensible way to solve some kind of absurd situation. Those situations were generally associated with Soviet bureaucracy, or lack of goods and common sense.

My first respondent (R1) described a situation when she was on duty, and she received a stupid command from her supervisor and then turned to her colleague for consolation. Her colleague told her a joke about a milkmaid called Leida Peips, a Soviet working hero who was selected by the communist party to represent Estonia in Moscow. Leida Peips was known as an example of the Soviet policy of "letting the working class rule". A fairly uneducated, but otherwise honest and hard-working woman was suddenly sent to Moscow where she had to represent Estonian interests in the Supreme Soviet ${ }^{2}$ of the Soviet Union. She later confessed that she was only an instrument in communists' hands (Suviste 2007). The joke about this milkmaid offered comfort and insight concerning the quality of the orders that came from higher officials.

My second respondent (R2) mentioned a plane trip which was diverted. Even if it had been possible to continue the flight after the problem was fixed, the pilots got drunk and all the passengers had to wait until the pilot became sober again. There was nothing else to do but joke about it.

The third respondent (R3) mentioned that political jokes were most successful in situations where people directly felt the oppression of the Soviet regime. Taking part in the parades was one such occasion where people told political jokes to one another to remain sane. He himself recalls that the 1st of May parade was extremely bothersome because you had to waste your day off for a parade, as participation in it was forced on people by the communist party.

2 Supreme Soviet was a substitute for a parliament in the Soviet Union. There were jokes that describe clapping of hands as the main activity of this institution: "People say that after arriving from Moscow, Leida Peips can no longer milk cows as her hands do not move up and down any more, but only apart and together again" (Sarv 1997). 


\section{Discussion}

Different respondents heard jokes in different locations, but they all seemed to have some common places where they heard most jokes or where they were sure to always hear jokes. One respondent said that "joking was everywhere". One common characteristic that could be used to describe the venues of joking is "closed room". Although participants perceived that "joking was everywhere", it is clear from their descriptions that the venues were fairly closed: they mentioned seminars, meetings, train compartments or similar venues where the number of participants was limited. None of the respondents claimed to hear or practice joking in front of a large and unknown audience. On the other hand, nor did they claim that joking was an utterly secret matter - far from that.

I can infer that joking situations were memorable for respondents because they successfully "solved" a real problem by joking. In a democratic society one might complement his or her emotions with rational actions while that was often impossible in the Soviet society. In the examples above (stupid orders, drunk pilots and the parade), there were no reasonable alternative actions, and joking might have been the only sensible approach to avoid personal distress. As Laineste (2002: 24) suggests "there is certain functionality to jokes as a mental tool for categorising and discussing social phenomena." Those three previously described situations as well as others that my respondents were telling me about could indeed be treated as "categorising and discussing a social phenomenon". By telling a political joke, one is hinting that "the parade of 1 st of May is ridiculous", for example.

If people in a democratic society are confronted with stupidity, they would probably get upset, swear, make a complaint, call for help or do something constructive - something that helps them to relieve tension and to solve the problem. This was often not possible in the Soviet Union - rules were usually set and officially they did not bend. Absurdities were not often even caused by the rules themselves but by a silly implementation of the rules. So the only sane way out of the situation was to turn it into a joke. The lack of possibilities in Soviet society might as well be described by a joke cited by Lewis (2006):

When was the first Russian election?

The time that God put Eve in front of Adam and said: "Go ahead, choose your wife."

One of my aims in this research was to study the context of joking in Soviet Estonia without forcing known interpretations like "safety valve" (Brandes 1977: 345) or "joking resistance" (Obrdlik 1942) on my respondents - the concepts that are heavily criticised by Davies (2011). Indeed, none of my respondents 
used those or similar terms. Instead, they were telling me about lively situations, stupid regulations in society and humanly aspects of joking. As a result I got quite a different view on the process of telling political jokes than might be expected from the literature.

Soviet society was a fertile ground for jokes, its golden era overlapping with late Brezhnev rule (1974-1982) in the Soviet Union (Krikmann 2009: 44). Absurdities of daily life might have provided enough material to stimulate the creation of thousands of political jokes, but as this study shows, there were also practical reasons for creating and telling such jokes, namely the lack of reasonable alternatives.

According to Davies, political jokes are "the aspirin of the people taken to suspend political pain" (Davies 2011: 248). I would suggest that people did not always necessarily feel the "pain" as political, but sometimes the "pain" was caused by inevitable stupidity.

\section{Limitations of the study}

This article presented was a pilot study designed to investigate the subject, hence it has its limitations. Firstly, the number of participants was quite small which does not allow any far reaching conclusions. Secondly, all participants were highly educated. When I compare my findings with Baločkaitè's (2011), who interviewed mainly working class people in Lithuania, there are obvious differences. For example, none of my respondents held basic needs like getting food for the family and schooling for the kids (Baločkaitè 2011: 422) as their primary concern during the 1970s. While this study had no such aim, my further research should clearly take social stratification into account.

\section{Conclusion}

Despite the limitations, this pilot study confirms that political jokes were widely told between highly educated people in the Soviet society. It demonstrates that at the same time, most joking occasions happened in smaller groups. The study also shows that political jokes were not a mere reflection of the absurdities of the Soviet society. They provided a straightforward approach for citizens to handle the frustrating situations caused by the social order. Respondents of this study offered several insights into such occasions. The act of telling political jokes sometimes had a highly practical value for them: it was a constructive approach when faced with unmanageable irrationality and stupidity. 


\section{Martin Rebane}

\section{References}

Baločkaitè, Rasa 2011. Pleasures of late socialism in Soviet Lithuania: Strategies of resistance and dissent. Journal of Baltic Studies 42(3), pp. 409-425.

Blane, David B. 1996. Collecting retrospective data: Development of a reliable method and a pilot study of its use. Social Science \& Medicine 42(5), pp. 751-757.

Brandes, Stanley H. 1977. Peaceful protest: Spanish political humor in a time of crisis. Western Folklore 36(4), pp. 331-346.

Bryant, Chad 2006. The language of resistance? Czech jokes and joke-telling under Nazi occupation, 1943-45. Journal of Contemporary History 41(1), pp. 133-151.

Cochran, Robert 1989. "What courage!": Romanian “Our leader” jokes. The Journal of American Folklore 102(405), pp. 259-274.

Davies, Christie 2011. Jokes and targets. Bloomington: Indiana University Press.

Davies, Christie 2010. Jokes as the truth about Soviet socialism. Folklore: Electronic Journal of Folklore 46, pp. 9-32.

Hong, Nathaniel 2010. Mow 'em all down grandma: The "weapon" of humor in two Danish World War II occupation scrapbooks. Humor - International Journal of Humor Research 23(1), pp. 27-64.

Krikmann, Arvo 2009. Jokes in Soviet Estonia. Folklore: Electronic Journal of Folklore 43, pp. 43-66.

Laineste, Liisi 2002. Take it with a grain of salt: The kernel of truth in topical jokes. Folklore: Electronic Journal of Folklore 21, pp. 7-25.

Laineste, Liisi 2008. Post-socialist jokes in Estonia: Continuity and change. Tartu: Tartu University Press.

Lewis, Ben 2006. Hammer \& tickle. Prospect Magazine, 20 May. http://www.prospectmagazine.co.uk/magazine/communist-jokes/, last accessed on 21 May 2012.

Obrdlik, Antonin J. 1942. "Gallows humor" - A sociological phenomenon. American Journal of Sociology 47(5), pp. 709-716.

Pi-Sunyer, Oriol 1977. Political humor in a dictatorial state: The case of Spain. Ethnohistory 24(2), pp. 179-190.

Sarv, Kadi 1997. Poliitiline anekdoot IV. [Political jokes IV.] Mäetagused, Vol. 5, pp. 79-87. http://www.folklore.ee/tagused/nr5/nalinet4.htm, last accessed on 12 February 2010.

Speier, Hans 1998. Wit and politics: An essay on power and laughter. American Journal of Sociology 103(5), pp. 1352-1401.

Suviste, Maarius 2007. Leida Peips: Lauta ma küll enam tööle ei läheks! [Leida Peips: I would not work in the cowbarn again!] Õhtuleht. http://www.ohtuleht.ee/242574, last accessed on 13 June 2012.

Thurston, Robert W. 1991. Social dimensions of stalinist rule: Humor and terror in the USSR, 1935-1941. Journal of Social History 24(3), pp. 541-562.

Tsakona, Villy \& Popa, Diana Elena 2011. Humour in politics and the politics of humour: An introduction. Studies in political humour: In between political critique and public entertainment. Amsterdam: John Benjamins Publishing Company, pp. 1-30. 